\title{
An approach to the new psychoactive drugs phenomenon
}

\author{
Helen Dolengevich-Segal, ${ }^{1,2}$ Beatriz Rodríguez-Salgado, ${ }^{3}$ Jorge Gómez-Arnau, ${ }^{1}$ Daniel Sánchez-Mateos ${ }^{4}$
}

1 Servicio de Psiquiatría, Hospital Universitario del Henares. Coslada, Madrid.

2 Fundación Psiformación. Madrid.

${ }^{3}$ Centro de Salud Mental de San Blas. Hospital Universitario Ramón y Cajal. Madrid.

${ }^{4}$ Hospital Universitario La Fe. Valencia.

Correspondence:

Helen Dolengevich-Segal

Servicio de Psiquiatría, Hospital

Universitario del Henares.

Avenida de Marie Curie s/n

28822 Coslada, Madrid, España.

Phone: (0034) 91191 - 2852.

E-mail: e.dolengevich@gmail.com

Received first version: April 20, 2016; Second version: December 5, 2016; Accepted: March 8, 2017.

https://doi.org/10.17711/ SM.0185-3325.2017.010

\begin{abstract}
Background. The new psychoactive drugs (NPD) are those that represent a danger to public health and are not prohibited by conventions on international narcotics. The concept also includes new contexts and new routes of consumption as well as novel ways of distribution, notably Internet. The risks associated with NPD consumption are largely unknown to users and to health care providers. Objective. To integrate the existing evidence regarding the main NPD in terms of description, epidemiology, psychopharmacology, medical complications and psychoactive effects. Method. To review relevant and updated clinical information on NPD obtained from specialized books and indexed scientific journals (PubMed/Medline, Google Scholar, Scopus), as well as official documents edited by international organizations dedicated to the epidemiologic analysis of drug abuse and Internet websites and forums managed by psychoactive substance users. Results. Aspects of clinical and pharmacological interest are described comprehensively, together with epidemiological data and risks associated to the consumption of the most relevant NPD: synthetic cannabinoids, synthetic cathinones, NBOMe series, indoleamines, piperazines, hallucinogenic mushrooms (Psilocybe SP.), synthetic opioids, plant products (khat, kratom, Salvia divinorum, ayahuasca) and dissociative anesthetics. Discussion and conclusion. The emergence of the NPD is a phenomenon on the rise with important consequences for public health. Learning about new trends in drug consumption and its potential risks should be essential for the medical professional. New research is needed in order to understand the phenomenon of the NPD and its pharmacological, clinical and legal implications.
\end{abstract}

Keywords: Spice, cathinone, psychoactive drugs, khat, opioids.

\section{RESUMEN}

Antecedentes. Las nuevas drogas psicoactivas (NDP) son aquellas que, aun cuando representan un peligro para la salud pública, no están prohibidas por los acuerdos internacionales sobre narcóticos. La noción incluye también nuevos contextos de usos, nuevas formas de administración y nuevas vías de distribución, entre las que destaca Internet. Los riesgos asociados al consumo de NDP son en gran medida desconocidos por los usuarios y el personal de salud. Objetivo. Integrar la información existente sobre las principales NDP en cuanto a su descripción, psicofarmacología, epidemiología, efectos psicoactivos y complicaciones médicas descritas. Método. Revisión de la información actualizada de relevancia clínica sobre las NDP obtenida de libros especializados y revistas científicas indexadas (PubMed/Medline, Google Scholar, Scopus); de documentos oficiales de organismos internacionales dedicados a la epidemiología del consumo de drogas, y de portales y foros en Internet gestionados por usuarios de sustancias psicoactivas. Resultados. Se describen de manera detallada aspectos de interés clínico y farmacológico, así como datos epidemiológicos y riesgos asociados al consumo de las NDP más relevantes: cannabinoides sintéticos, catinonas sintéticas, serie de los NBOMe, indolaminas, piperazinas, hongos alucinógenos (Psilocybe sp.), opioides sintéticos, productos vegetales (khat, kratom, Salvia divinorum, ayahuasca) y anestésicos disociativos. Discusión y conclusión. El surgimiento de las NDP es un fenómeno en auge con importantes consecuencias en la salud pública. Se hace imprescindible para el profesional médico conocer las nuevas tendencias en el consumo y los riesgos potenciales del mismo. Son necesarias también nuevas investigaciones para comprender el fenómeno de las NDP y sus implicaciones farmacológicas, clínicas y legales.

Palabras clave: Spice, catinona, drogas psicoactivas, khat, opioides. 


\section{BACKGROUND}

In the last decade, a change in the consumption of psychoactive substances has become evident. Changes have also been evident in the way of acquiring and distributing them, in which Internet has played a significant role. Illegal substances have displayed a stabilization or even a decrease in their consumption (Schifano, Orsolini, Duccio Papanti \& Corkery, 2015), while new drugs appear in the world market with growing prominence.

According to the United Nations Office on Drugs and Crime (UNODC), the term "new psychoactive drugs" (NPD) refers to substances that pose a threat to public health and are not regulated under the United Nations' Single Convention on Narcotic Drugs, 1961, or the Convention on Psychotropic Substances, 1961 (United Nations Office on Drugs and Crime, 2013). Likewise, the name NPD not only refers to newly synthesized substances, but it also encompasses other substances, which are already regulated, that are used outside their traditional contexts or are obtained through new distribution channels (Dolengevich-Segal, Rodríguez Salgado, Gómez-Arnau Ramírez \& Sánchez-Mateos, 2015).

The NPD are characterized for being cheap, easy to acquire, and, many times, legal, which makes them attractive to the consumer. They are frequently advertised as "legal highs", as well as "research chemicals". They are sold as "mystical incense", "water pipe cleaners", "bath salts", "collectors' items" or "plant food". The wrappings are appealing and have a label that reads "not for human consumption" or "for research purposes only", which allows them to avoid current legislations. The ingredients and components of the substances offered can be diverse, ranging from herbal products to synthetic products, with different effects: stimulant, sedative, empathogenic, hallucinogenic, analgesic or unknown (Dolengevich-Segal, Gómez-Arnau Ramírez, Rodríguez Salgado, Rabito Alcón \& Correas Lauffer, 2014). Their sale and distribution have significantly taken place through Internet, but they can also be obtained through other channels. Likewise, the NPD can appear on the market under the guise of supervised drugs or as an alternatives to said drug. For instance, methoxetamine was sold as a legal alternative to ketamine, while 25I-NBOMe has been sold both as if it were a legal option for LSD and as if it were LSD (Giné, Espinosa \& Vilamala, 2014; Lawn, Barratt, Williams, Horne \& Winstock, 2014).

The 2015 report form the European Monitoring Centre for Drugs and Drug Addiction (EMCDDA) mentions that, in 2014, 101 new psychoactive substances were detected, including cathinones and synthetic cannabinoids (European Monitoring Centre for Drugs and Drug Addiction, 2015). Since the inception of the EU Early Warning System (EWS) in 1997, about 450 have been identified and this figure increases every year. There is an estimation that around 2.9 million people between the ages of 15 and 24 (approximately 5\% overall population) in the United States have consumed NPD at least once (Corazza, Assi, Simonato et al., 2013).

Due to the difficulty in supervising these substances, there have been various approaches for trying to limit their use from the legal viewpoint. Thus, the EMCDDA, through the EWS, detects and advises the prohibition of substances. In this way, between 2009 and 2010, this organization advised the prohibition of piperazines, synthetic cannabinoids, and mephedrone (García-Repetto \& Soria, 2011). In 2014, various substances were analyzed in order to advise their prohibition: 25I-NBOMe, AH-7921, MDPV, and methoxetamine were evaluated in April, as were opioid MT-45 and amphetamine derivative 4,4'DMAR (European Monitoring Centre for Drugs and Drug Addiction, 2015).

Internet is the main distribution channel of the NPD. In 2013, the EMCDDA identified 651 websites that sold "legal highs" in Europe. There are other channels for acquiring substances, legal or illegal, in a deep stratum of Internet known as "Deep Web", in which the information is encrypted and avoids the vigilance from the authorities (Dolengevich-Segal, Rodríguez Salgado et al., 2015).

On the other hand, Internet has also opened the door for a fruitful exchange of information among consumers. The value of numerous forums, blogs or websites, in which experienced psychonauts describe their experiences or exchange information and opinions on substances, has progressively been acknowledged, seeking to contribute towards a more responsible usage (Davey, Schifano, Corazza, Deluca \& Psychonaut Web Mapping Group, 2012).

There are various risks entailed by the NPD. The fact that they are legal and cheap makes them accessible to young and inexperienced consumers. The newness of the molecules permits that both the expected and undesirable effects of these substances often be unknown and unpredictable. Adding to the complexity, they are undetectable in urine with the reagents usually employed in hospitals, which makes the accurate handling of intoxication cases more difficult. The treatment of patients intoxicated by the NPD in European emergency departments is increasingly being reported. An analysis performed by the European Drug Emergencies Network (Euro-DEN) in 2014 describes that about $6 \%$ of the emergencies were due to the use of the NPD (European Monitoring Centre for Drugs and Drug Addiction, 2015), which makes it necessary for the physician to know about the existence and possible effects of these NPD.

This review has the objective of integrating the existent information on the description, psychofarmacology, epidemiology, psychoactive effects and potential issues of the main NDP. 


\section{METHOD}

Literature on the subject published in the last 15 years was consulted. With the object of framing the review, a search was made in July, 2016 on Pubmed/Medline, Google Scholar and Scopus using the following search terms: "new psychoactive substances", "new psychoactive drugs", "bath salts", "legal highs", "research chemicals", as well as other specific terms for certain substances, such as "synthethic cannabinoids", "synthetic cathinones", "NBOMe", "khat", "kratom", to mention a few. Although information sources in both English and Spanish were included, the bibliographic review was made in English only. Likewise, the bibliography of the articles obtained was reviewed and the main textbooks specialized on the subject were consulted (Dolengevich-Segal, Gómez-Arnau Ramírez et al., 2015; Dargan \& Wood, 2013; Ott, 2000; Schultes \& Hofmann, 2000; Shulgin, 1991; Shulgin, 1997).

Documents published by official organizations (most notably, UNODC, EMCDDA, DEA) were included in order to obtain epidemiological and legislative data. Due to the persistently limited diffusion of the subject within scientific literature, particularly on the aspects related to the use of NPD on human subjects, it was contrasted with information available on the web, specifically on informative websites devoted to damage reduction, as well as particular forums in which users share their experiences (table 1).

With the goal of integrating a more useful and comprehensive review on the subject, the works included were selected through a critical and detailed evaluation of the information and the consensus of the authors. Reports of clinical cases, original investigations, and reviews with a clinical approach were included. Works related to biochemical aspects specific detection methods, toxicology or forensics were excluded. Considering the high renewal rate, even within a few months, of the available evidence regarding NPD, articles published preferably (though not exclusively) in the last three years were selected. The articles that were at last included in the review where those in which the clinical relevance of the consumption of NPD was predominant.

Once all sources were included, the information obtained was organized in relation to the most important NPD families: synthetic cannabinoids, synthetic cathinones, NBOMe, phenethylamines, tryptamines, piperazines, mushrooms, vegetables, synthetic opioids and new dissociative anesthetics.

\section{RESULTS}

\section{Synthetic cannabinoids}

Synthetic cannabinoids (SCs) are an enormous group of substances, with diverse chemical structures, having in common the affinity for cannabinoid receptors. Their consumption has multiplied in the last years among those who seek effects similar to those of cannabis with the promise of being legal and undetectable in toxicological tests (Dolengevich-Segal, Gómez-Arnau Ramírez et al., 2015).

Table 1

Web addresses related to New Psychoactive Drugs

\begin{tabular}{ll}
\hline Sites/consumer forums & \\
\hline In Spanish: & \\
http://www.cannabiscafe.org & \\
http://drogoteca.blogspot.com & \\
http://lisergia.org & \\
In English: & \\
http://www.erowid.org & \\
https://www.reddit.com & \\
http://www.drugs-forum.org & \\
http://www.bluelight.org & \\
http://www.psychonautwiki.org & \\
Institutional & \\
https://www.unodc.org & United Nations Office for Drugs and Crime \\
http://www.dea.gov & Drug Enforcement Administration \\
http://www.emcdda.europa.eu & European Monitoring Center for Drugs and Drug Addiction \\
http://www.pnsd.msc.es & Plan Nacional sobre Drogas (Spain) \\
$\begin{array}{ll}\text { Damage Reduction } \\
\text { http://www.talktofrank.com }\end{array}$ & FRANK (United Kingdom) \\
http://teens.drugabuse.gov & NIDA for teens (United States) \\
http://www.energycontrol.org & El Portal de Energy Control (Spain) \\
Research Projects & \\
http://www.psychonautproject.eu & Psychonaut Web Mapping Project \\
http://www.rednetproject.eu & ReDNeT \\
\hline Adapted from: Dolengevich-Segal, Rodriguez Salgado, Gómez-Arnau Ramírez, Frenzi Rabito Alcón \& Correas \\
Lauffer, 2014.
\end{tabular}


SCs are the largest group of NPD known to date, since at the end of 2014, a total of 134 SCs were reported through EMCDDA (European Monitoring Centre for Drugs and Drug Addiction, 2015). These products are distributed with various names, such as "Spice", "K2", "Aroma", "Yucatan Fire", among many others, and most recently, "Psyclones" (Santacroce et al., 2015).

They are presented as herbal preparations that are sold in brightly colored packages, which highlight in their advertising the legality and presumed innocuousness of the product. They are advertised as "mystical incense", "meditation potpourri" or "air fresheners", and can be easily acquired through Internet, as well as in stores aimed towards the sale of cannabis cultivation paraphernalia or other similar establishments. These packages contain various dried herbs with an appearance similar to that of marijuana (Pedicularis densiflora, Leonotis leonurus, Nynphea or Althaea, to mention a few) ready to be smoked, although these can be found prepared for oral or injected consumption. In fact, most products contain various SCs in a single preparation, which increases the risk of severe intoxications and overdoses (Schifano et al., 2015).

At least 14 different families of SCs have been described, whose chemical structures are not related to THC, since they have a different metabolism and greater toxicity (Castaneto et al., 2014). Active principles are molecules that are structurally small, liposoluble, apolar and volatile (which makes smoked consumption easier) (Vardakou, Pistos \& Spiliopoulou, 2010). First generation SCs refer mostly to JWH, HU and AM compounds. In the last years, second generation SCs have been identified, such as AB-PINACA, 5F-AB-PINACA, ADB-PINACA, AKB-48(APINACA), 5F-AKB-48 and AB-FUBINACA (Uchiyama, Kawamura, Kikura-Hanajiri \& Goda, 2013; Zawilska \& Andrzejczak, 2015).

Many of these SCs display a fluorization of their structure, which increases potency, extends their half-life and allows better stability. Also, other second generation compounds, such as UR-144, 5F-AKB-48 and 4-(methylnaphtyl)-AM-2201, have proved to be cytotoxic on recent studies (Bileck et al., 2016).

SCs tend to have a high affinity for endogenous cannabinoid receptors, both $\mathrm{CB} 1$ and $\mathrm{CB} 2$, which implies a greater potency than natural cannabis. Additionally, some SCs have other pharmacodynamic actions, like antagonism to the NMDA receptor (Schiffano et al., 2015), inhibition capacity for MAO (Fisar, 2010) or agonism for the 5-HT2A receptor (Halberstadt, 2015; Yip \& Dart, 2014), which contributes to the development of psychotic symptomatology and serotonin syndrome (Boyer \& Shannon, 2005).

The great number of SCs with their increasing potency places them as substances that pose an important risk on public health. Thus, SCs toxicity reports in the United States increased from 349 in January, 2015, to 1501 in April of the same year (Law, Schier, Martin, Chang \& Wolkin, 2015). Likewise, a study performed in the United States on a sample of 12000 adolescents found that up to $10 \%$ of the students had used SCs in the previous 12 months and 3.2\% acknowledged a frequent use of at least six times in the same time frame (Palamar \& Acosta, 2015).

Acute SCs intoxication is characterized by anxiety, agitation, visual and/or auditory hallucinations, tachycardia, hypertension, mydriasis, hyperglycemia, dyspnoea, nausea/ vomiting and seizures. Serious complications such as encephalopathy, strokes, kidney damage and death have appeared as well (Dolengevich-Segal, Gómez-Arnau Ramírez et al., 2015; Hermanns-Clausen, Kneisel, Szabo \& Auwärter, 2013). Deaths have been associated both with consumption of SCs in isolation or combined with other products, such as O-desmethyltramadol in a product called "Krypton" (Fattore \& Fratta, 2011).

Prolonged use of SCs has been linked both to tolerance and dependency (Gunderson, Haughey, Ait-Daoud, Joshi \& Hart, 2012), as well as to prolonged and severe withdrawal syndrome (Zimmermann et al., 2009). Likewise, the risk of presenting psychosis has been widely described and can be dose-dependent (Di Forti et al., 2014; Celofiga, Koprivsek \& Klavz, 2014).

\section{Synthetic cathinones}

Synthetic cathinones (SCAs) are a large group of amphetamine $\beta$-ketonic compounds derived from cathinone, a psychoactive component naturally found in a plant consumed traditionally in the Horn of Africa (Kalix \& Braenden, 1985). These substances have been, for some years now, the main active components of the so called "bath salts" or "plant food", which is why they are considered NPD (Dolengevich-Segal, Gómez-Arnau Ramírez et al., 2015). Among their psychotropic actions, users describe a entactogen effect similar to that of MDMA and a stimulant effect like that of cocaine (McElrath \& O'Neill, 2011). From this group of substances, the most popular has been mephedrone or 4-methylmethcathinone, as well as ephedrone, methylone and MDPV (3,4-methylenedioxypyrovalerone).

However, since the prohibition of this first generation of SCAs, there was an emergence of new compounds, such as 4-methyl-N-ethcathinone (4-MEC), 4-methyl- $\alpha$-pyrrolidinopropiophenone (4-MePPP; 4-MPPP) and $\alpha$-pyrrolidinovaleorophenone ( $\alpha-\mathrm{PVP})$, analogous to MDPV. These last two stand out because of the media attention that arose due to their presumed influence on subjects with severe and grotesque behavior disorders. Thus, the media referred to MDVP as a "cannibal drug" and $\alpha-P V P$ as "flakka" (Gómez-Arnau, Rodríguez-Salgado, Sánchez-Mateos \& Dolengevich-Segal, 2015).

Cathinones acutely increase the levels of extracellular dopamine, noradrenaline and serotonin by inhibiting 
their reuptake (López-Arnau, Martínez-Clemente, Pubill, Escubedo \& Camarasa, 2012). Additionally, they increase presynaptic liberation of monoamines by reverting the regular transporter flux, in a similar fashion as that of amphetamines (Baumann et al., 2012). Each SCAs has a different selectivity for each monoaminergic transporter, which determines the variability of its effects and potency (Schifano et al., 2015).

SCAs can be presented as powder, crystals, tablets or capsules. They can be administered in various ways, such as intranasally, orally, rectally, intravenously, intramuscularly or subcutaneously. The way in which they are administered also determines the potency of the effects and their duration.

Psychoactive effects include euphoria, excitability and increased alert and energy levels. Numerous cases of delirium have been described, with hallucinations, agitation and aggressiveness associated with adrenergic symptomatology such as tachycardia, hypertension, restlessness, sweating and pupil dilatation, among others. It has recently been demonstrated that second generation SCAs have a high hepatotoxic potential (Araújo, Valente et al., 2015). Likewise, severe psychopathology has been associated with these substances, including mood swings and suicidal behavior, anxiety, hallucinations and paranoid ideation. Serious complications such as rhabdomyolysis, kidney failure, seizures and death have been reported for various compounds of this family.

Various cathinones create also tolerance, dependency and withdrawal symptomatology (Schifano et al., 2011).

Mephedrone is the SCA that brings together the most epidemiological data, since it is a very popular NPD in the United Kingdom. In the 2015 survey on mephedrone consumption in England and Wales for young persons between the ages of 16 and 24, it was detected that the consumption of this substance occurred in $1.9 \%$ of this population, which is a lower figure than the one registered in 2011 with $4.4 \%$, a year before control measures were adopted (European Monitoring Centre for Drugs and Drug Addiction, 2015).

In the last few years, the intravenous use of mephedrone and other cathinones has been detected in men who have sex with men (MSM), which implies risky sexual intercourse with a high probability of contagion of viral infections such as HIV or hepatitis C, as well as sexually transmitted diseases and mental disorders, and so it has become a public health issue in European countries (Dolengevich-Segal, Rodríguez-Salgado, Gómez-Arnau \& Sánchez-Mateos, 2016).

\section{NBOMe Series}

NBOMe are a subgroup of phenethylamines, with psychedelic effects, that derive fundamentally from $2 \mathrm{C}$ series compound through the insertion of a methoxybenzyl group (BOMe) at the level of amino nitrogen (Bersani et al., 2014). These substances were synthesized for the first time in the 2000s and cited on scientific literature from 2011 onwards. Their most common denomination is "N-bomb", although they can also be found as "pandora" or "smile", to mention a few.

NBOMe act as partial agonists with a high affinity of the serotonin receptor 5-HT2A (Zuba, Sekuła \& Buczek, 2013), as well as a possible agonist $\alpha-1$ adrenergic activity (Tang, Ching, Tsui, Chu \& Mak, 2014). They are typically consumed in blotter orally or sublingually, although presentations are diverse. They have become popular as a "legal alternative" to LSD, or have also been sold/consumed as if they were LSD (Dolengevich-Segal, Gómez-Arnau Ramírez et al., 2015).

These NPD can give way to a wide spectrum of psychedelic phenomena, many of them intensely unpleasant, depending on the dose. Perception of time gets distorted and visual and auditory hallucinations, and visual illusions with kaleidoscopic images can appear. Synesthetic phenomena and cenestopathies are frequent, and may provoke mystical experiences, as well as an altered consciousness (Kyriakou et al., 2015). Sympathomimetic stimulation appears with tachycardia, hypertension, diaphoresis or mydriasis, as well as nausea and vomiting, headaches or transient dysuria. There are reports of cases of coldness and hypoesthesia of the limbs with potential risk of necrosis by peripheral vasoconstriction. Also, conversely from the safety expected from LSD, consumption of NBOMe (especially 25I-NBOMe) has caused social alarm due to more than ten deaths reported since 2012 (Andreasen, Telving, Rosendal, Eg, Hasselstrøm \& Andersen, 2015; Kueppers \& Cooke, 2015). In some cases, death was nearly immediate (Walterscheid et al., 2014; Poklis et al., 2014). For this reason, in July 2012, the United Kingdom included 25C-, 25B-, 25I- and 25D-NBOMe as controlled substances and in the United States they were prohibited in 2013. Although there are few epidemiological data regarding the consumption of these substances, the 2013 Global Drugs Survey showed that from 22289 participants, $582(2.6 \%)$ had consumed some NBOMe at least once, 25I-NBOMe being the most frequent one (Wood, Sedefov, Cunningham \& Dargan, 2015).

\section{Indoleamines: tryptamines and lysergamides}

Indoleamines are the serotonergic hallucinogenic drugs par excellence. They are versatile molecules, used in millenarian ceremonies from their natural sources or as synthetic products in recreational contexts. They are grouped into simple and compound tryptamines (also known as ergolines, lysergamides or ergot alkaloids).

Their presence is widespread both in the vegetable kingdom (N,N-dimethyltryptamine or DMT found in Amazonian lianas), the fungi (psilocybine in fungi of the genus Psilocybe) and even the animal (bufotenine isolated from the skin of batrachians of the genus Bufus) (Dolengevich-Segal, Gómez-Arnau Ramírez et al, 2015). 
Pharmacokinetic properties of tryptamines of synthetic origin have been mainly deduced from the behavior of natural tryptamines, such as DMT. This substance is not active orally, since it is degraded by monoamine oxidase enzymes (MAO) of the digestive tract. If entheogenic activity is sought orally, it must be combined with a MAO activity inhibitor, whether it is natural (such as $\beta$-carbolines) or synthetic (Fantegrossi, Murnane \& Reissig, 2008).

Tryptamines have low affinity for the 5-HT2A serotonin receptor when compared to other hallucinogenic drugs. They also exercise their action on 5-HT1A, 5-HT2C receptors, vesicular monoamine transporter type 2 (VMAT2) and receptor $\sigma 1$. Those with an $\alpha$-methyl group show a more powerful stimulant activity than the rest and slow down the inactivation by MAO enzymes, which causes a longer lasting effect as well as the possibility to be consumed orally (Appendino, Minassi \& Taglialatela-Scafati, 2014).

UNODC mentions the appearance of 25 new tryptamines reported from 2009 until July 2012; since then and until the end of the year 2013, only two were reported. Tryptamines most frequently used among consumers are $\alpha$-methyltryptamine (AMT) and three kinds of 5-methoxytryptamines: 5-MeO-DMT, 5-MeO-DiPT (Foxy Methoxy) and N,N-dyalil-5-methoxytriptamine or 5-MeO-DALT. Users talk about different levels of intensity, which can be better distinguished in long trips: a basic experience of colors, geometric shapes, radical changes in the space-time conception and in fundamental emotionality; a level of autobiographical introspection with symbolic variations within a state of lucidity, with visionary abilities in a full conscience oneiric scenario and, finally, the so-called peak experiences (Rodríguez-Salgado, Gómez-Arnau Ramírez, Sánchez-Mateos \& Dolengevich-Segal, 2016).

Tryptamines are not generally considered to be substances with cardiovascular vital risk due to their lack of affinity to related receptors; however, deaths have been linked to consumption of AMT, particularly when combined with other substances such as 3,4-methyl-N-dioxypyrovalerone, cocaine, amphetamines, cathinone, MDMA and cannabinoids (World Health Organization, 2014).

Psychotic symptoms and panic reactions are frequent in the consumption of DMT, particularly when inhaled and with 5-MeO-DiPT (Araújo, Carvalho et al., 2015). Cases of severe intoxication and deaths have been reported with the use of bufotenine, as well as deaths by 5-MeO-DALT and 5-MeO-DiPT used rectally. Likewise, some deceases due to the consumption of a positional isomer of alpha-methyltryptamine, the so called 5-IT, led to its regulation at a European level (Dolengevich-Segal, Gómez-Arnau Ramírez et al, 2015).

The main representative with psychedelic action among ergolines is lysergic acid diethylamide or LSD. Notwithstanding, and considering the strict restriction this substance is subject to, other molecules in the same family have been in- cluded within the NPD category. In a study carried out in the United Kingdom, among the "herbal highs" most frequently requested in the Internet were "Hawaiian Baby Woodrose" seeds (Schmidt, Sharma, Schifano \& Feinmann, 2011), which are traditionally used in Ayurvedic medicine. Such seeds contain lysergic acid amide, also known as ergine or LSA, as well as tropane alkaloids with an anticholinergic effect.

\section{Piperazines}

The piperazine derivatives most frequently consumed as recreational substances are BZP (1-benzylpiperazine), MDBP 1-(3,4-methylenedioxy benzyl) piperazine, TFMPP (3-trifluoromethylphenyl) piperazine and MeOPP 1-(4-methoxyphenyl) piperazine.

These organic compounds have a psychostimulant effect similar to that of amphetamines, though of a lesser potency. They have gained popularity within the NPD market for trying to emulate the effect of MDMA, being thence known as "party pills", "herbal highs" or "herbal ecstasy". In fact, the popular party pill "Molly" is usually a combination of MDMA and piperazines (Kersten \& McLaughlin, 2015). Apart from the expected sympathomimetic effects, on a high dose these compounds may work as hallucinogenic drugs due to their agonist effect of the 5-HT2A receptors. The principal adverse effects to have been reported are hepatotoxicity, convulsive crises, hyponatremia, serotonin syndrome and kidney failure (Arbo et al., 2016).

The consumption of piperazines has descended considerably since their prohibition. In New Zealand, where consumption has been considerable, prevalence of use of BZP in general population descended from 15.3\% in 2006 to $3.2 \%$ in 2009 (Wilkins \& Sweetsur, 2013). Thus, other legal NPDs have entered the market in order to substitute such compounds.

\section{Hallucinogenic mushrooms: Psilocybe sp}

Hallucinogenic mushrooms, also known as magic mushrooms belong to the spiritual and healing culture of Mesoamerican peoples (there is also proof of its traditional use in the islands of the South Pacific). Relegated to secrecy during the Conquest, they were recovered in the hippie movement for the progressive Western World and globally spread in our days via the Internet.

Its active principle psilocybine, and psylocyne are simple tryptamines from a chemical viewpoint. By means of a central serotonin receptor, as well as dopaminergic, among others, they induce perception changes, modifications in meanings as well as in the emotionality associated to memories that occasionally end up in transcendental experiences (Tylš, Páleníček \& Horáček, 2014). On a peripheral level, they cause a sympathomimetic syndrome: nausea and vomiting, tachycardia, elevation of blood pressure and/or of 
body temperature, in direct relation with the dosage used (Hasler, Grimberg, Benz, Huber \& Vollenweider, 2004). Just as with the rest of the simple tryptamines, psylocyne and psilocybine are considered substances with a wide margin of safety. Only one single decease has been reported up to date, and this was related with the massive consumption of Psilocybe semilanceata, as well as persistent perceptive disorder incidents due to hallucinogenic drugs (Espiard, Lecardeur, Abadie, Halbecq \& Dollfus, 2005). Though both active principles are listed under category I of addictive substances, with no therapeutic potential acknowledged, anti-migraine or anti-obsessive properties have been reported. Likewise, a recent viability study mentions the use of psilocybine, along with psychological support, as an effective treatment for resistant depression (Carhart-Harris, 2016).

\section{Synthetic opioids: desomorphine, AH-7291 and MT-45}

There are many synthetic opioids with abuse potential that are commercialized, legally or illegally, through the Internet. Our attention is focused upon three molecules of this group due to different reasons. Desomorphine, better known by its common name "krokodil", is a substance that is paradigmatic of the household synthesis of drugs with dramatic consequences; on the other hand, both AH-7291 and MT-45 duly represent the dynamics of creation of legal substances that are later supervised, after confirming their potential risks.

Krokodil is an opioid made from codeine pills and easy access chemical substances: phosphorus, gasoline, iodine and chlorhydric acid, among others. Though it can be used by different channels, users tend to inject it endovenously. Its boom, in Russia, Ukraine and other Eastern Europe countries is related to the low supply of heroine coming from Afghanistan along with the impossibility of addicts to enroll in damage reduction programs. The powerful opioid effect of krokodil numbs the areas where it is administered, which accounts for consumers' indifference of soft tissue and bone necrosis. It has also been related to thyroid disorders, thrombophlebitis, inner organ swelling and the decease of the addict around six months after starting consumption (Thekkemuriyi, John \& Pillai, 2014).

AH-7291 is a synthetic opioid available in the illegal market since the year 2012, which has been found in samples of a product known as Doxylam (Zawilska \& Andrzejczak, 2015). Research studies in animals have proven that this substance provokes an analgesia as powerful as that induced by morphine; a lower risk than morphine to inhibit respiratory function or to provoke hypothermia seems more controverted (Coppola \& Mondola, 2015). AH-7921 may induce dependence. It is an agonist of opioids $\mu$ and $\mathrm{k}$ receptors, with a narrow therapeutic margin, as is the case with morphine. Its preferred way of administration is oral, though also intra- venous, intranasal, sublingual or intrarectal administrations have been reported.

Confiscations of AH-7921 have usually taken place in small amounts of dust. In 2013, it was detected in six cases of non-lethal intoxication and in fifteen cases of death in Sweden, the United Kingdom and Norway, combined with other depressor substances such as benzodiazepines, synthetic cathinones, alcohol, metoxetamine or gabapentine. Lung edema was found during the autopsy in most of the deadly victims (Ledberg, 2015).

MT-45 was developed in the 70's in a Japanese laboratory. It is an agonist of opioids $\mathrm{K}, \mu$ and $\delta$ receptors, with analgesic and sedative effects, prone to promote respiratory depression and cognitive deficit; it also has a highly addictive potential. Its administration is typically oral or by nasal aspiration, though it has also been reported to have been administered intravenously, intrarectally or inhaled. Among the sought effects is moderate euphoria, relaxation and a sensation of well-being. At least 30 deceases have been reported, most of them in Switzerland, as well as numerous clinically relevant intoxications. Post-mortem studies have revealed consumption of this opioid combined with other substances that are depressors of the central nervous system such as alcohol, benzodiazepines, cannabis or dissociatives (Siddiqi, Verney, Dargan \& Wood, 2015). An epidemiologic work on drug use in Switzerland (STRIDA-project) detected non-lethal intoxications for MT-45, which responded to naloxone in the emergency room, as well as cases of bilateral hearing loss associated to the consumption of this opioid (Helander, Bäckberg \& Beck, 2014). In December 2013, EMCDDA proposed its inclusion in NPD listings and a year later the EU confirmed it.

\section{Vegetables like NPDs: sage, khat, kratom and ayahuasca}

Salvia divinorum is an endemic plant from the North Oaxaca region (Mexico) where Mazateca shamans have used it in healing and divination rituals (Ujváry, 2014). Its use in the Western world has increasingly expanded since the second half of the 20th century until around two decades ago, when it started being offered in smart shops. Now it is being distributed in the Internet, making it the most highly demanded natural psychedelic. This plant is widely used in North America as a recreational substance for young persons. For instance, a Canadian study obtained from a representative sample of 42179 adolescents between 12 and 17 years of age detected that $3.8 \%$ of that population had used sage in the last year and $6.2 \%$ had used it sometime in their lives (Currie, 2013).

It is important to underscore the difference between the traditional way of consumption, slowly chewing the leaves, and the popular way, by inhaling extracts of the plant of different potencies. The active substance of $S$. divinorum 
is salvinorine A, a potent selective agonist of $\mathrm{K}$ opioid receptors, whose effects seem to be related to its activity at the claustrum level (Stiefel, Merrifield \& Holcombe, 2014). Though it does not provoke real hallucinations, intoxication by $S$. divinorum causes notable changes in all perceptive channels, including the identity and transcendence realms on higher dosage. Its consumption has been associated with psychosis in people who are predisposed (El-Khoury \& Sahakian, 2015).

Khat (Catha edulis) is a bush native of the Horn of Africa and the Arabic Peninsula, where its leaves are traditionally chewed in social gatherings. Active substances are cathinones, stimulating substances altering the natural flow of dopamine and noradrenaline in the cell membrane, causing a sympathomimetic profile at a systemic level (Wabe, 2011). Beyond its use within migrant population from regions where khat is a native species and apart from its use in non-traditional ways, its extension as NPD comes from the inspiration for the synthesis of one of the most frequently mentioned new drugs of abuse: synthetic cathinones (Griffiths et al., 2010). Chronic consumption of khat has been associated to an increase in cardiovascular mortality, in digestive morbidity, in dysplasia and oral cancer, as well as in sexual dysfunction and in risk of abortion. Likewise, on a psychopathological level, it may worsen a pre-diagnosed psychosis or provoke acute paranoid reactions (Odenwald et al., 2005).

The leaves of the Mytragina speciosa bush, endemic of Southeast Asia, the Philippine Islands and New Guinea, are used to make certain products of vegetable origin that are consumed as an invigorating remedy, as aphrodisiac and analgesic, under the name kratom (Ahmad \& Aziz, 2012). Its active substance is mitraginine, a $\delta$ and $\mu$ opioid receptor agonist (Stolt et al., 2014). It is mainly used by oral administration, infusing the leaves in boiling water, though there are reports of inhaled administration by smoking dried extracts of kratom. The effect is similar to opiate intoxication, though in the first stages a stimulant effect seems to be predominant. As other opioids, it has been associated to a potent withdrawal syndrome after suspending it, as well as to tolerance phenomena (Singh, Müller \& Vicknasingam, 2014). Some consumers seem to use it to alleviate the withdrawal symptoms secondary to dependence of other opioids or to treat chronic pain (Rodríguez-Salgado et al., 2016). Thus, in the last decade, a noteworthy expansion in its use in the Western world has taken place, which has been easier because of online commerce, until becoming one of the psychoactive substances most frequently present on the Internet (Schmidt et al., 2011).

Table 2

Other new psychoactive drugs

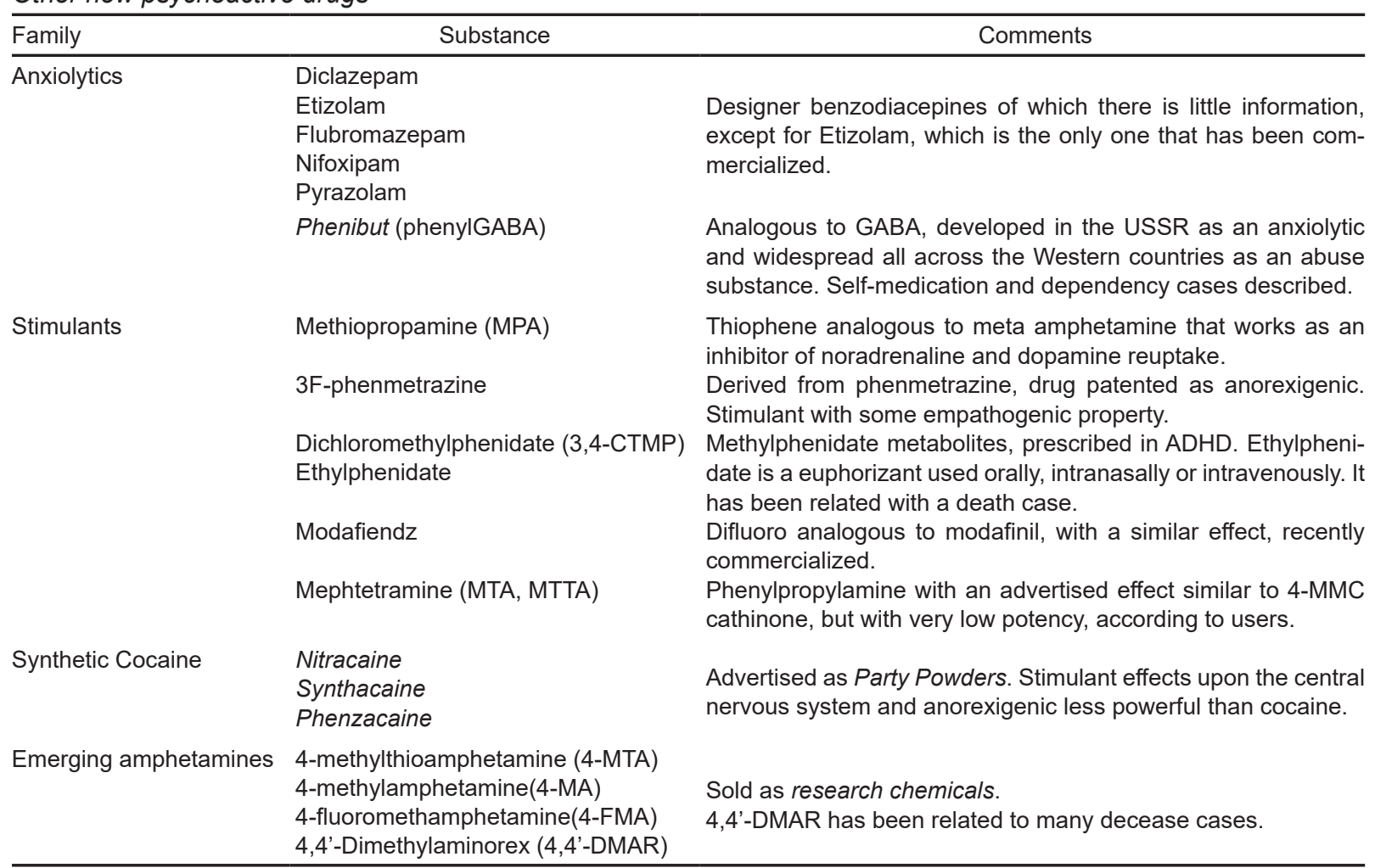

Adapted from: Dolengevich-Segal, Gómez-Arnau Ramírez et al., 2015. 
Ayahuasca is a vegetable beverage cooked on fire, a lightly dense liquid for oral administration that is native to the Amazon forest; it contains, at least, two kinds of plants: the Banisteriopsis caapi vine (a source of harmine and harmaline, with a monoamine oxidase inhibiting action -IMAO) and the Psychotria viridis bush (rich in DMT). Cooking methods as well as other ingredients added to the concoction are variable according to tradition of every particular region, but they all have in common their healing and visionary use (Ott, 2000; Schultes \& Hofmann, 2000). Ayahuasca has the peculiarity of being psychoactive as long as it has both active substances, considering that orally, triptamines are degraded by intestinal MAO and only the presence of inhibitors of this enzyme allow it to reach the central nervous system (Riba et al., 2003). It must also be underscored that this drink has aroused the interest of professionals devoted to the treatment of addictions, particularly alcohol and cocaine. In the Peruvian rain forest, the Takawasi Center has offered encouraging results to addicts, acknowledging the healing properties of the intake of ayahuasca along with community interaction with a multidisciplinary team for some months (Winkelman, 2014).

Interest in ayahuasca as NPD lies on its being widespread in the Western world. Since the end of the last century it has been consumed among progressive groups, some of them ascribed to religious congregations which acknowledge the intake of the concoction as a sacrament; its consumption is thence not prosecuted by the law in those countries which have a certain religious freedom. In the last decades, its ingredients, whether from vegetable sources or in synthetic forms, are available via online commerce.

\section{New dissociative anesthetics: methoxetamine and diphenidine}

Methoxetamine (2-(3-methoxyphenyl)-2-(ethylamino) cyclohexanone) is a derivative of ketamine (Kjellgren \& Jonsson, 2013). In vitro studies have confirmed that both methoxetamine and the new PCP analogues are akin to NMDA type glutamate receptors. Since 2010, methoxetamine has been sold on the Internet as a whitish powder that can be aspired by the nose, under names such as "Mexxy", "MXE" or "Special M". After an outstanding expansion, it was supervised in the United Kingdom in 2012 (Corazza, Assi \& Schifano, 2013). According to testimonies of users, clinical effects of methoxetamine are similar to those of ketamine, but with a greater onset latency and a longer lasting effect. In low dosage, it has a euphorizing and socializing effect, while on high doses, dissociation is predominant. Among its somatic effects one can underscore sympathetic stimulation, cerebellar ataxia, confusion and agitation. There have been numerous deceases associated to the consumption of this substance (Zawilska \& Andrzejczak, 2015).
After methoxetamine control, new dissociative anesthetics have appeared in the market: diphenidine and 2-methoxydiphenidine. They are also NMDA-type receptor antagonists. They are usually consumed orally, nasally or sublingually as powders. Among the effects, users underscore its stimulant, empathogenic and hallucinogenic power (Van Hout \& Hearne, 2015; Helander, Beck \& Bäckberg, 2015). Recently, several deaths have been described as related to the use of 2-methoxydiphenidine (Elliot et al., 2015).

The Energy Control Project, from NGO Bienestar y Desarrollo, is devoted to the reduction of risks in drug consumption in Spain. Its Internet site warns about the sale of diphenidine as adulterant in ecstasy pills at the end of 2014, and about the commercialization of deschloroketamine as ketamine in the beginning of 2016 (table 2).

\section{DISCUSSION AND CONCLUSION}

New psychoactive drugs appear in the market, characterized by being legal, by its rapid reconversion at being supervised, by their availability, their use within new contexts or by new ways of administration and, in many cases, by their potential risks to public health.

Synthetic cannabinoids can be underscored by their frequent mention in scientific literature. They are molecules closely related to endogenous cannabinoid receptors, which provoke an effect similar to that of cannabis, though with a greater incidence of medical and psychiatric complications. Synthetic cathinones can also be underscored. They are stimulant compounds based on their natural forms and they have been cause of debate in the media. Also, phenethylamines, such as NBOMe series, new synthetic opioids, new generation dissociative anesthetics, piperazines or natural products such as mushrooms or vegetables with a traditional use, have been detected within recreational consumption. It is highly relevant to undertake new research projects to study the real effect on a neurochemical level and the potential risks for health derived from NPDs, as well as the true consumption prevalence and complications, the epidemiological profile of consumers and the legal situation of these drugs. Likewise, evidence of NPD use among intoxicated patients that attend hospital emergency services implies the need for greater knowledge by health care providers about their use and effects, as well as the development of adequate toxicology detection techniques that are effective in the clinical realm.

\section{Funding}

None.

\section{Conflict of interest}

The authors declare they have no conflict of interest. 


\section{REFERENCES}

Ahmad, K., \& Aziz, Z. (2012). Mitragyna speciosa use in the northern states of Malaysia: a cross-sectional study. Journal of Ethnopharmacology, 141(1), 446-50. https://doi.org/10.1016/j.jep.2012.03.009

Andreasen, M. F., Telving, R., Rosendal, I., Eg, M. B., Hasselstrøm, J. B., \& Andersen, L. V. (2015). A fatal poisoning involving 25C-NBOMe. Forensic Science International, 251, e1-8. https://doi.org/10.1016/j.forsciint.2015.03.012

Araújo, A. M., Carvalho, F., Bastos, M. de L., Guedes de Pinho, P., \& Carvalho, M. (2015). The hallucinogenic world of tryptamines: an updated review. Archives of Toxicology, 89(8), 1151-73. https://doi.org/10.1007/s00204-015-1513-x

Araújo, A. M., Valente, M. J., Carvalho, M., Dias da Silva, D., Gaspar, H., Carvalho, F., ... Guedes de Pinho, P. (2015). Raising awareness of new psychoactive substances: chemical analysis and in vitro toxicity screening of "legal high" packages containing synthetic cathinones. Archives of Toxicology, 89(5), 757-71. https://doi.org/10.1007/s00204-014-1278-7

Arbo, M. D., Melega, S., Stöber, R., Schug, M., Rempel, E., Rahnenführer, J., ... Hengstler, J. G. (2016). Hepatotoxicity of piperazine designer drugs: up-regulation of key enzymes of cholesterol and lipid biosynthesis. Archives of Toxicology, 90(12), 3045-3060. https://doi.org/10.1007/s00204-016-1665-3

Appendino, G., Minassi, A., \& Taglialatela-Scafati, O. (2014). Recreational drug discovery: natural products as lead structures for the synthesis of smart drugs. Natural Product Reports, 31(7), 880-904. https://doi.org/10.1039/c4np00010b

Baumann, M. H., Ayestas, M. A., Partilla, J. S., Sink, J. R., Shulgin, A. T., Daley, P. F., ... Cozzi, N. V. (2012). The designer methcathinone analogs, mephedrone and methylone, are substrates for monoamine transporters in brain tissue. Neuropsychopharmacology : Official Publication of the American College of Neuropsychopharmacology, 37(5), 1192-203. https://doi.org/10.1038/ npp.2011.304

Bersani, F. S., Corazza, O., Albano, G., Valeriani, G., Santacroce, R., Bolzan Mariotti Posocco, F., ... Schifano, F. (2014). 25C-NBOMe: preliminary data on pharmacology, psychoactive effects, and toxicity of a new potent and dangerous hallucinogenic drug. BioMed Research International, 2014, 734749. https://doi. org/10.1155/2014/734749

Bileck, A., Ferk, F., Al-Serori, H., Koller, V. J., Muqaku, B., Haslberger, A., ... Knasmüller, S. (2016). Impact of a synthetic cannabinoid (CP-47,497-C8) on protein expression in human cells: evidence for induction of inflammation and DNA damage. Archives of Toxicology, 90(6), 1369-82. https://doi.org/10.1007/ s00204-015-1569-7

Boyer, E. W., \& Shannon, M. (2005). The serotonin syndrome. The New England Journal of Medicine, 352(11), 1112-20. https://doi.org/10.1056/NEJMra041867

Carhart-Harris, R. L., Bolstridge, M., Rucker, J., Day, C. M. J., Erritzoe, D., Kaelen, M., ... Nutt, D. J. (2016). Psilocybin with psychological support for treatment-resistant depression: an open-label feasibility study. The Lancet. Psychiatry, 3(7), 619-27. https://doi.org/10.1016/S2215-0366(16)30065-7

Castaneto, M. S., Gorelick, D. A., Desrosiers, N. A., Hartman, R. L., Pirard, S., \& Huestis, M. A. (2014). Synthetic cannabinoids: epidemiology, pharmacodynamics, and clinical implications. Drug and Alcohol Dependence, 144, 12-41. https://doi.org/10.1016/j.drugalcdep.2014.08.005

Celofiga, A., Koprivsek, J., \& Klavz, J. (2014). Use of synthetic cannabinoids in patients with psychotic disorders: case series. Journal of Dual Diagnosis, 10(3), 168-73. https://doi.org/10.1080/15504263.2014.929364

Coppola, M., \& Mondola, R. (2015). AH-7921: a new synthetic opioid of abuse. Drug and Alcohol Review, 34(1), 109-10. https://doi.org/10.1111/dar.12216

Corazza, O., Assi, S., \& Schifano, F. (2013). From "Special K" to "Special M": the evolution of the recreational use of ketamine and methoxetamine. CNS Neuroscience \& Therapeutics, 19(6), 454-60. https://doi.org/10.1111/cns.12063

Corazza, O., Assi, S., Simonato, P., Corkery, J., Bersani, F. S., Demetrovics, Z., ... Schifano, F. (2013). Promoting innovation and excellence to face the rapid diffusion of novel psychoactive substances in the EU: the outcomes of the ReDNet project. Human Psychopharmacology, 28(4), 317-23. https://doi.org/10.1002/hup.2299

Currie, C. L. (2013). Epidemiology of adolescent Salvia divinorum use in Canada. Drug and Alcohol Dependence, 128(1-2), 166-70. https://doi.org/10.1016/j. drugalcdep.2012.08.008
Dargan PI \& Wood DM (Eds) (2013). Novel Psychoactive Substances: Classification, Pharmacology and Toxicology. London: Elsevier; 2013.ISBN: 978-0-12415816-0.

Davey, Z., Schifano, F., Corazza, O., Deluca, P., \& Psychonaut Web Mapping Group. (2012). e-Psychonauts: conducting research in online drug forum communities. Journal of Mental Health (Abingdon, England), 21(4), 386-94. https://doi.org/1 $0.3109 / 09638237.2012 .682265$

Di Forti, M., Sallis, H., Allegri, F., Trotta, A., Ferraro, L., Stilo, S. A., ... Murray, R. M. (2014). Daily use, especially of high-potency cannabis, drives the earlier onset of psychosis in cannabis users. Schizophrenia Bulletin, 40(6), 1509-17. https://doi.org/10.1093/schbul/sbt181

Dolengevich Segal, H., Gómez-Arnau Ramírez, J., Rodríguez Salgado, B., Rabito Alcón, M. F., \& Correas, J. (2014). Panorama actual en el uso de drogas emergentes. Health and Addictions: Salud Y Drogas, 14(1), 47-58. Retrieved from http://dialnet.unirioja.es/servlet/articulo? codigo $=4782685 \&$ info $=$ resumen\&idioma $=$ SPA

Dolengevich Segal, H., Rodríguez Salgado, B., Gómez-Arnau Ramírez, J., Frenzi Rabito Alcón, M., \& Correas Lauffer, J. (2014). Uso de sustancias psicoactivas en la era de Internet Psychoactive substance use in the Internet era. Revista de Patología Dual, 1(2). https://doi.org/10.17579/RevPatDual.01.6

Dolengevich Segal H., Gómez-Arnau Ramírez J., Rodríguez Salgado B., \& Sánchez-Mateos D. (Eds.) (2015). Nuevas Drogas Psicoactivas. España: Entheos. ISBN:978-84-940824-7-4.

Dolengevich-Segal, H., Rodríguez Salgado, B., Gómez-Arnau Ramírez, J., \& Sánchez-Mateos, D. (2015). New Psychoactive Drugs. Adicciones, 27(3), 231-2. DOI: https://doi.org/10.20882/adicciones.709

Dolengevich-Segal, H., Rodríguez-Salgado, B., Gómez-Arnau, J., \& Sánchez-Mateos, D. (2016). Severe Psychosis, Drug Dependence, and Hepatitis C Related to Slamming Mephedrone. Case Reports in Psychiatry, 2016, 8379562. https:// doi.org/10.1155/2016/837956

El-Khoury, J., \& Sahakian, N. (2015). The Association of Salvia divinorum and Psychotic Disorders: A Review of the Literature and Case Series. Journal of Psychoactive Drugs, 47(4), 286-92. https://doi.org/10.1080/02791072.2015.1 073815

Elliott, S. P., Brandt, S. D., Wallach, J., Morris, H., \& Kavanagh, P. V. (2015). First reported fatalities associated with the "research chemical" 2-methoxydiphenidine. Journal of Analytical Toxicology, 39(4), 287-93. https://doi.org/10.1093/ jat/bkv006

Espiard, M.-L., Lecardeur, L., Abadie, P., Halbecq, I., \& Dollfus, S. (2005). Hallucinogen persisting perception disorder after psilocybin consumption: a case study. European Psychiatry : The Journal of the Association of European Psychiatrists, 20(5-6), 458-60. https://doi.org/10.1016/j.eurpsy.2005.04.008

European Monitoring Centre for Drugs and Drug Addiction. (2015), New psychoactive substances in Europe. An update from the EU Early Warning System (March 2015), Publications Office of the European Union, Luxembourg. ISBN: 978-92-9168-764-0 doi:10.2810/372415.

Fantegrossi, W. E., Murnane, K. S., \& Reissig, C. J. (2008). The behavioral pharmacology of hallucinogens. Biochemical Pharmacology, 75(1), 17-33. https://doi. org/10.1016/j.bcp.2007.07.018

Fattore, L., \& Fratta, W. (2011). Beyond THC: The New Generation of Cannabinoid Designer Drugs. Frontiers in Behavioral Neuroscience, 5, 60. https://doi. org/10.3389/fnbeh. 2011.00060

Fisar, Z. (2010). Inhibition of monoamine oxidase activity by cannabinoids. Naunyn-Schmiedeberg's Archives of Pharmacology, 381(6), 563-72. https:// doi.org/10.1007/s00210-010-0517-6

García-Repetto, R., Soria, ML. (2011). Drogas emergentes: una perspectiva médico-legal. Rev Esp Med Legal, 37(2):76-82. http://dx.doi.org/10.1016/S03774732(11)70067-0

Giné, C. V., Espinosa, I. F., \& Vilamala, M. V. (2014). New psychoactive substances as adulterants of controlled drugs. A worrying phenomenon? Drug Testing and Analysis, 6(7-8), 819-24. https://doi.org/10.1002/dta.1610

Gómez-Arnau, J., Rodríguez-Salgado, B., Sánchez-Mateos, D., \& Dolengevich-Segal, H. (2015). “FLAKKA ":Una nueva droga psicoactiva en España. Revista de Patología Dual, 2(4), 6-7. https://doi.org/10.17579/RevPatDual.02.20 
Griffiths, P., Lopez, D., Sedefov, R., Gallegos, A., Hughes, B., Noor, A., \& Royuela, L. (2010). Khat use and monitoring drug use in Europe: the current situation and issues for the future. Journal of Ethnopharmacology, 132(3), 578-83. https:// doi.org/10.1016/j.jep.2010.04.046

Gunderson, E. W., Haughey, H. M., Ait-Daoud, N., Joshi, A. S., \& Hart, C. L. (2012). "Spice" and "K2" herbal highs: a case series and systematic review of the clinical effects and biopsychosocial implications of synthetic cannabinoid use in humans. The American Journal on Addictions, 21(4), 320-6. https://doi. org/10.1111/j.1521-0391.2012.00240.x

Halberstadt, A. L. (2015). Recent advances in the neuropsychopharmacology of serotonergic hallucinogens. Behavioural Brain Research, 277, 99-120. https://doi. org/10.1016/j.bbr.2014.07.016

Hasler, F., Grimberg, U., Benz, M. A., Huber, T., \& Vollenweider, F. X. (2004). Acute psychological and physiological effects of psilocybin in healthy humans: a double-blind, placebo-controlled dose-effect study. Psychopharmacology, 172(2), 145-56. https://doi.org/10.1007/s00213-003-1640-6

Helander, A., Bäckberg, M., \& Beck, O. (2014). MT-45, a new psychoactive substance associated with hearing loss and unconsciousness. Clinical Toxicology (Philadelphia, Pa.), 52(8), 901-4. https://doi.org/10.3109/15563650.2014.943908

Helander, A., Beck, O., \& Bäckberg, M. (2015). Intoxications by the dissociative new psychoactive substances diphenidine and methoxphenidine. Clinical Toxicology (Philadelphia, Pa.), 53(5), 446-53. https://doi.org/10.3109/15563650. 2015.1033630

Hermanns-Clausen, M., Kneisel, S., Szabo, B., \& Auwärter, V. (2013). Acute toxicity due to the confirmed consumption of synthetic cannabinoids: clinical and laboratory findings. Addiction (Abingdon, England), 108(3), 534-44. https://doi. org/10.1111/j.1360-0443.2012.04078.x

Kalix, P., \& Braenden, O. (1985). Pharmacological aspects of the chewing of khat leaves. Pharmacological Reviews, 37(2), 149-64. Retrieved from http://www. ncbi.nlm.nih.gov/pubmed/2864707

Kersten, B. P., \& McLaughlin, M. E. (2015). Toxicology and management of novel psychoactive drugs. Journal of Pharmacy Practice, 28(1), 50-65. https://doi. org/10.1177/0897190014544814

Kjellgren, A., \& Jonsson, K. (2013). Methoxetamine (MXE)--a phenomenological study of experiences induced by a "legal high" from the internet. Journal of Psychoactive Drugs, 45(3), 276-86. https://doi.org/10.1080/02791072.2013.8 03647

Kueppers, V. B., \& Cooke, C. T. (2015). 25I-NBOMe related death in Australia: a case report. Forensic Science International, 249, e15-8. https://doi.org/10.1016/j. forsciint.2015.02.010

Kyriakou, C., Marinelli, E., Frati, P., Santurro, A., Afxentiou, M., Zaami, S., \& Busardo, F. P. (2015). NBOMe: new potent hallucinogens--pharmacology, analytical methods, toxicities, fatalities: a review. European Review for Medical and Pharmacological Sciences, 19(17), 3270-81. Retrieved from http://www.ncbi.nlm. nih.gov/pubmed/26400534

Law, R., Schier, J., Martin, C., Chang, A., \& Wolkin, A. (2015). Increase in reported adverse health effects related to synthetic cannabinoids use - United States. MMWR. 64(22); 618-619

Lawn, W., Barratt, M., Williams, M., Horne, A., \& Winstock, A. (2014). The NBOMe hallucinogenic drug series: Patterns of use, characteristics of users and self-reported effects in a large international sample. Journal of Psychopharmacology (Oxford, England), 28(8), 780-8. https://doi. org/10.1177/0269881114523866

Ledberg, A. (2015). The interest in eight new psychoactive substances before and after scheduling. Drug and Alcohol Dependence, 152, 73-8. https://doi. org/10.1016/j.drugalcdep.2015.04.020

López-Arnau, R., Martínez-Clemente, J., Pubill, D., Escubedo, E., \& Camarasa, J. (2012). Comparative neuropharmacology of three psychostimulant cathinone derivatives: butylone, mephedrone and methylone. British Journal of Pharmacology, 167(2), 407-20. https://doi.org/10.1111/j.1476-5381.2012.01998.x

McElrath, K., \& O'Neill, C. (2011). Experiences with mephedrone pre- and post-legislative controls: perceptions of safety and sources of supply. The International Journal on Drug Policy, 22(2), 120-7. https://doi.org/10.1016/j. drugpo.2010.11.001

Observatorio Europeo de las Drogas y las Toxicomanías (2016), Informe Europeo so- bre Drogas 2016: Tendencias y novedades, Oficina de Publicaciones de la Unión Europea, Luxemburgo. ISBN: 978-92-9168-869-2 doi:10.2810/7535.

Odenwald, M., Neuner, F., Schauer, M., Elbert, T., Catani, C., Lingenfelder, B., ... Rockstroh, B. (2005). Khat use as risk factor for psychotic disorders: a cross-sectional and case-control study in Somalia. BMC Medicine, 3, 5. https:// doi.org/10.1186/1741-7015-3-5

Ott J. (2000). Pharmacotheon. España: Los Libros de la Liebre de Marzo.ISBN: 84 87403-23-9.

Palamar, J. J., \& Acosta, P. (2015). Synthetic cannabinoid use in a nationally representative sample of US high school seniors. Drug and Alcohol Dependence, 149, 194-202. https://doi.org/10.1016/j.drugalcdep.2015.01.044

Poklis, J. L., Devers, K. G., Arbefeville, E. F., Pearson, J. M., Houston, E., \& Poklis, A. (2014). Postmortem detection of 25I-NBOMe [2-(4-iodo-2,5-dimethoxyphenyl)-N-[(2-methoxyphenyl)methyl]ethanamine] in fluids and tissues determined by high performance liquid chromatography with tandem mass spectrometry from a traumatic death. Forensic Science International, 234, e14-20. https://doi.org/10.1016/j.forsciint.2013.10.015

Riba, J., Valle, M., Urbano, G., Yritia, M., Morte, A., \& Barbanoj, M. J. (2003). Human pharmacology of ayahuasca: subjective and cardiovascular effects, monoamine metabolite excretion, and pharmacokinetics. The Journal of Pharmacology and Experimental Therapeutics, 306(1), 73-83. https://doi.org/10.1124/ jpet.103.049882

Rodríguez Salgado, B., Gómez-Arnau Ramírez, J., Sánchez Mateos, D., \& Dolengevich Segal, H. (2016). [Vegetables as new psychoactive drugs: a narrative review]. Medwave, 16(1), e6372. DOI. 10.5867/medwave.2016.01.6372. Retrieved from http://www.ncbi.nlm.nih.gov/pubmed/26937890

Santacroce, R., Corazza, O., Martinotti, G., Bersani, F. S., Valeriani, G., \& Di Giannantonio, M. (2015). Psyclones: a roller coaster of life? Hidden synthetic cannabinoids and stimulants in apparently harmless products. Human Psychopharmacology, 30(4), 265-71. https://doi.org/10.1002/hup.2410

Schultes, RE., Hofmann, A. (2000). Plantas de los Dioses. México DF: Fondo de Cultura Económica. ISBN: 968-16-6303-9.

Schifano, F., Albanese, A., Fergus, S., Stair, J. L., Deluca, P., Corazza, O., ... ReDNet Research Groups. (2011). Mephedrone (4-methylmethcathinone; "meow meow"): chemical, pharmacological and clinical issues. Psychopharmacology, 214(3), 593-602. https://doi.org/10.1007/s00213-010-2070-x

Schifano, F., Orsolini, L., Duccio Papanti, G., \& Corkery, J. M. (2015). Novel psychoactive substances of interest for psychiatry. World Psychiatry, 14(1), 15-26. http://doi.org/10.1002/wps.20174.

Schmidt, M. M., Sharma, A., Schifano, F., \& Feinmann, C. (2011). "Legal highs" on the net-Evaluation of UK-based Websites, products and product information. Forensic Science International, 206(1-3), 92-7. https://doi.org/10.1016/j. forsciint.2010.06.030

Shulgin, A. (1991). PiHKAL: A Chemical Love Story. California: Transform Press. ISBN 10: 0963009605 ISBN 13: 9780963009609

Shulgin, A. (1997). TiHKAL: The Continuation. California: Transform Press. ISBN 10: 0963009699 ISBN 13: 9780963009692

Siddiqi, S., Verney, C., Dargan, P., \& Wood, D. M. (2015). Understanding the availability, prevalence of use, desired effects, acute toxicity and dependence potential of the novel opioid MT-45. Clinical Toxicology (Philadelphia, Pa.), 53(1), 54-9. https://doi.org/10.3109/15563650.2014.983239

Singh, D., Müller, C. P., \& Vicknasingam, B. K. (2014). Kratom (Mitragyna speciosa) dependence, withdrawal symptoms and craving in regular users. Drug and Alcohol Dependence, 139, 132-7. https://doi.org/10.1016/j.drugalcdep.2014.03.017

Stiefel, K. M., Merrifield, A., \& Holcombe, A. O. (2014). The claustrum's proposed role in consciousness is supported by the effect and target localization of Salvia divinorum. Frontiers in Integrative Neuroscience, 8, 20. https://doi.org/10.3389/ fnint.2014.00020

Stolt, A.-C., Schröder, H., Neurath, H., Grecksch, G., Höllt, V., Meyer, M. R., ... Becker, A. (2014). Behavioral and neurochemical characterization of kratom (Mitragyna speciosa) extract. Psychopharmacology, 231(1), 13-25. https://doi. org/10.1007/s00213-013-3201-y

Tang, M. H. Y., Ching, C. K., Tsui, M. S. H., Chu, F. K. C., \& Mak, T. W. L. (2014) Two cases of severe intoxication associated with analytically confirmed use of 
the novel psychoactive substances 25B-NBOMe and 25C-NBOMe. Clinical Toxicology (Philadelphia, Pa.), 52(5), 561-5. https://doi.org/10.3109/1556365 0.2014 .909932

Thekkemuriyi, D. V, John, S. G., \& Pillai, U. (2014). "Krokodil"--a designer drug from across the Atlantic, with serious consequences. The American Journal of Medicine, 127(3), e1-2. https://doi.org/10.1016/j.amjmed.2013.09.030

Tylš, F., Páleníček, T., \& Horáček, J. (2014). Psilocybin--summary of knowledge and new perspectives. European Neuropsychopharmacology : The Journal of the European College of Neuropsychopharmacology, 24(3), 342-56. https://doi. org/10.1016/j.euroneuro.2013.12.006

Uchiyama, N., Kawamura, M., Kikura-Hanajiri, R., \& Goda, Y. (2013). URB754: a new class of designer drug and 12 synthetic cannabinoids detected in illegal products. Forensic Science International, 227(1-3), 21-32. https://doi. org/10.1016/j.forsciint.2012.08.047

Ujváry, I. (2014). Psychoactive natural products: overview of recent developments. Annali dell'Istituto Superiore Di Sanita, 50(1), 12-27. https://doi.org/DOI: 10.4415/ANN_14_01_04

United Nations Office on Drugs and Crime (2013). The challenge of new psychoactive substances. Available at: http://www.unodc.org/documents/scientific/NPS 2013_SMART.pdf

Van Hout, M. C., \& Hearne, E. (2015). "Word of mouse": indigenous harm reduction and online consumerism of the synthetic compound methoxphenidine. Journal of Psychoactive Drugs, 47(1), 30-41. https://doi.org/10.1080/02791072.2014. 974002

Vardakou, I., Pistos, C., \& Spiliopoulou, C. (2010). Spice drugs as a new trend: mode of action, identification and legislation. Toxicology Letters, 197(3), 157-62. https://doi.org/10.1016/j.toxlet.2010.06.002

Walterscheid, J. P., Phillips, G. T., Lopez, A. E., Gonsoulin, M. L., Chen, H.-H., \& Sanchez, L. A. (2014). Pathological findings in 2 cases of fatal 25I-NBOMe toxicity. The American Journal of Forensic Medicine and Pathology, 35(1), 20-5. https://doi.org/10.1097/PAF.0000000000000082
Wabe, N. T. (2011). Chemistry, pharmacology, and toxicology of khat (catha edulis forsk): a review. Addiction \& Health, 3(3-4), 137-49. Retrieved from http:// www.ncbi.nlm.nih.gov/pubmed/24494129

Wilkins, C., \& Sweetsur, P. (2013). The impact of the prohibition of benzylpiperazine (BZP) "legal highs" on the prevalence of BZP, new legal highs and other drug use in New Zealand. Drug and Alcohol Dependence, 127(1-3), 72-80. https:// doi.org/10.1016/j.drugalcdep.2012.06.014

Winkelman, M. (2014). Psychedelics as medicines for substance abuse rehabilitation: evaluating treatments with LSD, Peyote, Ibogaine and Ayahuasca. Current Drug Abuse Reviews, 7(2), 101-16. DOI: 10.2174/18744737086661501 07120011

Wood, D. M., Sedefov, R., Cunningham, A., \& Dargan, P. I. (2015). Prevalence of use and acute toxicity associated with the use of NBOMe drugs. Clinical Toxicology (Philadelphia, Pa.), 53(2), 85-92. https://doi.org/10.3109/15563650.2 015.1004179

World Health Organization. (2014). Alpha methyltryptamine (AMT). Critical Review. in: WHO Expert Committee on Drug Dependence. Thirty-sixth, WHO Technical Report Series No. 991. Geneva, Suiza. Retrieved from: http://www. who.int/medicines/areas/quality_safety/4_20_EPR_2.pdf?ua=1.

Yip L \& Dart CR (2014). Is there something more about synthetic cannabinoids? Forensic Toxicol,32:340-1. DOI: 10.1007/s11419-013-0224-3

Zawilska, J. B., \& Andrzejczak, D. (2015). Next generation of novel psychoactive substances on the horizon - A complex problem to face. Drug and Alcohol Dependence, 157, 1-17. https://doi.org/10.1016/j.drugalcdep.2015.09.030

Zimmermann, U. S., Winkelmann, P. R., Pilhatsch, M., Nees, J. A., Spanagel, R., \& Schulz, K. (2009). Withdrawal phenomena and dependence syndrome after the consumption of "spice gold". Deutsches Arzteblatt International, 106(27), 464-7. https://doi.org/10.3238/arztebl.2009.0464

Zuba, D., Sekuła, K., \& Buczek, A. (2013). 25C-NBOMe--new potent hallucinogenic substance identified on the drug market. Forensic Science International, 227(1-3), 7-14. https://doi.org/10.1016/j.forsciint.2012.08.027 